\author{
( В. М. АНТОНЮК-КИСІЛЬ ${ }^{1}$, В. М. ЄНІКЕЄВА ${ }^{1}$, С. І. ЛІЧНЕР ${ }^{1}$, В. М. ЛИПНИЙ ${ }^{1}$, М. В. СЕМЕНЮК ${ }^{2}$ \\ КЗ “Рівненський обласний перинатальний центр” Рівненської обласної ради \\ ТзОВ "ЛОКО", м. Рівне ${ }^{2}$
}

\title{
Дуплексне сканування нетипових форм прогресуючої варикозної хвороби підшкірних вен у вагітних (зовнішніх статевих органів, промежини)
}

\begin{abstract}
Мета роботи: вивчити, використовуючи дані дуплексного сканування, джерела та варіанти прогресуючої варикозної хвороби підшкірних вен промежини, зовнішніх статевих органів під час вагітності.

Матеріали і методи. Обстежено згідно з розробленим нами протоколом 768 (93,03 \%) пацієнток із 825 вагітних 3 варикозною хворобою нижніх кінцівок, промежини, зовнішніх статевих органів, пахового каналу, які народжували в обласному перинатальному центрі з початку 2013 до 2016 р. включно.

Результати досліджень та їх обговорення. Основним доступним на даний час, динамічним, інформативним, малотравматичним для вагітних і плода методом обстеження венозної системи таза, промежини і нижніх кінцівок, паху при прогресуючому варикозному розширені вен у цих ділянках є дуплексне сканування. Дуплексне сканування проводили для вивчення анатомії венозної системи прогресуючої варикозної хвороби вищеперерахованих ділянок із плануванням доцільності та по можливості безпечної хірургічної корекції даної патології з визначенням об’єму операційного втручання під час вагітності. Одним із етапів дуплексного сканування $є$ виявлення зон із патологічним рефлюксом, визначених нами як “вузлові ділянки” венозної системи, які, за нашими даними, в більшості випадків є пусковим механізмом розвитку і причиною прогресування варикозного розширення підшкірних вен вищеперерахованих ділянок.
\end{abstract}

Ключові слова: причини прогресуючої варикозної хвороби у вагітних; варикозне розширення вен вульви і промежини; дуплексне сканування вен.

Постановка проблеми і аналіз останніх досліджень та публікацій. Варикозне розширення вен зовнішніх статевих органів, промежини під час вагітності як самостійне захворювання виявляють у 3,7-30 \% пацієнток. Зустрічається у вигляді двобічного ураження зовнішніх статевих губ - у 43,5 \% вагітних, лівобічного - у 27 \% вагітних і правобічного - у 29,5 \% пацієнток. Дана патологія може бути в поєднанні у 14-20 \% вагітних з варикозним розширенням вен піхви і прямої кишки як єдиної ознаки прояву варикозної хвороби вен таза при відсутності проявів тазового венозного повнокров'я, незважаючи на значну варикозну трансформацію гонадних вен і венозних тазових сплетень [10, 12, 14]. Розширення вульварних вен виникало в більшості випадків у жінок з двома і більше доношеними вагітностями (91 \%) в терміни 12-24 (78 \%) тижні. Найчастіше помічають цю патологію у терміни вагітності 18-20 тижнів [2]. При цьому кожна повторна вагітність проявлялася в більш ранні терміни. Помічено, що у 20 \% вагітних вульварний варикоз зберігається і збільшується 3 часом у віддаленому періоді $[12,14]$. Це анатомічно зумовлено тим, що зовнішні соромітні вени дренують кров із промежини, з верхнього відділу та медіальної поверхні стегна, зовнішніх статевих органів і впадають у проксимальний відділ великої підшкірної вени (ВПВ) по медіаль- ній її поверхні на протязі 5 см від співустя. У 3040 \% випадків одна із зовнішніх статевих вен впадає по задній поверхні ВПВ перед самим співустям. Тому виникнення патологічного венозного рефлексу (ПВР) із термінального відділу ВПВ в ці гілки приводить до варикозного розширення цих вен [10]. Бурлева Е. П. і співавт. (2016) [1] досліджували ПВР у вени промежини, які були варикозно розширені. Виявили, що у 92,3 \% пацієнток був ПВР у вени промежини через гілки із стовбура ВПВ. В останній час звертається увага на місце впадання приток ВПВ у термінальній її частині відносно остіального клапана [8, 9]. Окрім того, зовнішня соромітна вена має велике значення у формуванні колатерального кровообігу, значно збільшуючись у діаметрі. V. pudenda ext. формує анастомози з однойменною веною з протилежної сторони, що представлено венозним сплетенням у підшкірній клітковині у ділянці лобка. Варикоз лобкової частини статевих губ при вагітності частіше виникає у вагітних, які готуються стати матерями не вперше, це явище часте і доволі серйозне. Воно може виникати раптово до кінця другого місяця вагітності, під час другої чи наступних вагітностей, частіше безсимптомно. Як вказує ряд авторів [13, 19], система зовнішньої соромітної вени складається із поверхневої зовнішньої соромітної і глибокої зовнішньої соромітної вени. Остання в 
50 \% випадків впадає у загальну стегнову вену, в 30 \% - у ділянку співустя ВПВ і в 20 \% - дистальніше 5 см від співустя [19]. Окрім того, в ділянку підшкірно-стегнового співустя у ВПВ впадає три постійні вени: з медіального боку - зовнішня статева вена, з переднього боку - поверхнева надчеревна вена і з латеральної поверхні - поверхнева вена, що оточує клубову кістку. Поряд із підшкірно-стегневим співустям у ВПВ можуть впадати також 1-2 так званих прихованих приток, які спостерігаються у 40 \% хворих із варикозним розширенням підшкірних вен [13,19]. У працях Б. А. Долго-Сабурова (1956) [3] описано також формування зв’язків венозного сплетення зовнішніх статевих органів через систему v. pudenda interna, як гілки внутрішньої клубової вени, із системою внутрішніх клубових вен, тазових венозних сплетень і затульними венами. V. pudenda int. через foramen infrapiriforme направляється з нижнього поверху порожнини малого таза, дренує кров із зовнішніх статевих органів [5]. У роботі E. Balian et al. відмічено, що v. pudenda int. анастомозує із ВПВ і зовнішньою соромітною веною через мережу поверхневих і глибоких дорзальних вен клітора або безпосередньо анастомозує між внутрішньою соромітною та зовнішньою соромітною венами статевих губ. Внутрішня соромітна вена також утворює анастомози з венами промежини та затульними [12].

Мета роботи: вивчити, використовуючи дані дуплексного сканування, джерела та варіанти прогресуючої варикозної хвороби підшкірних вен промежини, зовнішніх статевих органів під час вагітності.

Матеріали і методи. На базі комунального закладу “Обласний перинатальний центр” Рівненської обласної ради з початку 2013 до 2016 р. включно народжували 14093 пацієнтки, із них 825 (5,85 \%) вагітних із варикозною хворобою нижніх кінцівок, промежини, зовнішніх статевих органів та пахового каналу. У 196 (23,76 \%) вагітних дана патологія була до першої вагітності, а у 629 (76,24 \%) пацієнток при наступних вагітностях (двоє і більше). Анамнестично в обстежених нами пацієнток в 90,1 \% випадків захворювання мало спадковий характер. Серед них було 15 (1,8 \%) пацієнток із справжнім рецидивом варикозної хвороби, які попередньо оперовані з причини варикозної хвороби нижніх кінцівок: 5 пацієнток з причини варикозної хвороби підшкірних вен нижніх кінцівок до першої вагітності, а 10 вагітних - у проміжку між вагітностями. У 7,9 \% вагітних запідозрили недиференційовану дисплазію сполучної тканини, у 0,5 \% пацієнток - уродже- ну артеріовенозну мальформацію з гіпоактивними артеріовенозними норицями на гомілці, а в 1,5 \% пацієнток - як прояв перенесеного флеботромбозу глибоких вен нижніх кінцівок і таза.

У 719 (87,15 \%) пацієнток скарги були зумовлені клінічними проявами захворювання (набряки, судоми, тяжкість у нижніх кінцівках та ін.), тоді як 106 (12,85 \%) пацієнток в основному турбували косметичні прояви захворювання, особливо наявність розширених підшкірних вен, ретикулярних вен на відкритих поверхнях кінцівок (гомілки, стопи, підколінна ділянка), на зовнішніх статевих органах та промежині. Серед 659 (79,9 \%) пацієнток спостерігали прогресування варикозної хвороби під час вагітності. Найбільша кількість пацієнток (569 (68,9 \%)) відмітила прогресування варикозної хвороби в II триместрі вагітності. Із 825 вагітних 3 варикозною хворобою нижніх кінцівок, зовнішніх статевих органів, промежини та пахового каналу 768 (93,09 \%) пацієнткам проведено дуплексне сканування басейну внутрішніх, зовнішніх клубових вен та вен нижніх кінцівок (поверхневих та глибоких), промежини, зовнішніх статевих органів. Вивчали джерела формування варикозного розширення вен промежини та зовнішніх статевих органів. Для дослідження підшкірної венозної системи, глибоких вен нижніх кінцівок, клубових вен проводили дуплексне сканування за допомогою апарата LANWIND MIRROR II з лінійним датчиком частотою 8-10 MHZ. Для отримання достовірних даних дослідження вен у вагітних у 100 \% виконували в положенні лежачи на лівому боці під кутом 15-30 градусів. Таке положення вагітної на лівому боці запобігає розвитку в цієї категорії пацієнток, особливо при кінці II і впродовж III триместрів вагітності під час обстеження, синдрому нижньої порожнистої вени або аортокавального синдрому. Крім того, здійснювали дослідження у стоячому (ортостазі) положенні, коли напружені м'язи нижніх кінцівок, особливо м'язів гомілок (включена м’язова помпа гомілки). Ортостаз (ортодинаміка) ближче всього до фізіологічного стану. Крім того, використовували пробу Вальсальви для збільшення венозного потоку, який особливо важливий для виявлення та вивчення наявності патологічного рефлюксу [18]. Необхідно звернути увагу на те, що не всі пацієнти можуть правильно виконати пробу Вальсальви, що не дає можливості виявити ПВР в обстежуваній вені [16]. У вагітних дуплексне сканування виконували переважно в другій половині дня, коли наростають гемодинамічні порушення у венозній системи (відчуття важкості в нижніх кінцівках, промежині, набряки, парестезії) [11]. Також ми проводили так 
звану пробу екстравазальної компресії доступних нам для цього варикозно розширених підшкірних вен пахового каналу, підшкірно-стегнової ділянки для виявлення можливих змін венозної гемодинаміки в системі вен, з яких виникали рефлюкси, оцінюючи, чи не погіршувалась венозна гемодинаміка, чи не наростало повнокров'я у венозних басейнах, звідкіля виникав патологічний рефлюкс. Ми не вивчали діаметри стовбурів ВПВ і/або МПВ та їх гілок. Для нас мала велике значення наявність ПВР по них і його поширеність. 3 метою підвищення достовірності результатів дуплексного сканування проводили оцінку шляхом поєднання результатів дуплексного сканування із даними клінічного огляду пацієнток. Це менш стосувалось ділянок великої підшкірної вени, особливо підшкірно-стегнового співустя, для якого чутливість і специфічність дуплексного сканування варіюють від 70 до 90 \%. Більше стосувалось обстеження малої підшкірної вени і перфорантних вен. Чутливість дуплексного сканування при дослідженні в ділянці “кросу” малої підшкірної вени складала 35-75 \%, специфічність дещо вища - до 90 \%, чутливість до перфорантних вен - близько 50 \%. На думку А.-A. Ramelet i співавт. [17], має місце розходження у 29 \% випадків між результатами клінічних обстежень і дуплексним скануванням, і 24 \% пацієнтів було б оперовано, коли б показання до операції базувалися тільки на показаннях дуплексного сканування.

Метою дуплексного сканування було не тільки вияснення причин прогресування варикозного розширення підшкірних вен, але й націленість на можливість хірургічної корекції даної патології та визначення об’єму операційного втручання для активної безмедикаментозної профілактики ускладнення варикозної хвороби підшкірних вен під час вагітності, пологів і в післяпологовому періоді.

У вагітних має місце обмеження обстеження методом дуплексного сканування ділянок клубових вен (загальних, внутрішніх клубових вен та початкового відділу нижньої порожнистої вени) за рахунок вагітної матки, яка перекриває доступ до огляду вищеперерахованих відрізків вен.

Результати досліджень та їх обговорення. Відповідно до Українського консенсусу з лікування пацієнтів з варикозною хворобою нижніх кінцівок $(2005)$ [7, 12] у вагітних використали другий рівень діагностики - дуплексне сканування. Даний метод не $є$ інвазійним, не викликає явних ятрогенних ускладнень як з боку вагітної, так і плода. При потребі виконували повторно. Цей метод дослідження надав нам майже всі дані, не- обхідні для встановлення діагнозу, можливість оцінити динаміку процесу і вибрати стратегію подальшого лікування. Крім того, В-режим візуалізує венозну структуру, що допомогло нам визначити траєкторію інтрафасціальних шляхів варикозних вен і точно їх локалізувати. Він дозволив нам оцінити анатомію поверхневої венозної системи, визначити прохідність і стан клапанного апарату різних сегментів поверхневих, глибоких вен, виявити неспроможність клапанів підшкірних і перфорантних вен, диференціювати венозну й артеріовенозну мальформацію. Необхідність детального вивчення причин прогресуючого варикозного розширення підшкірних вен зовнішніх статевих органів, вен пахового каналу, промежини під час вагітності спричинена неефективністю консервативної терапії в лікуванні даної патології. Для цього треба було вияснити особливості в розвитку варикозного процесу під час вагітності у вищеперерахованих венозних басейнах і способи запобігання цьому з мінімальним негативним впливом на перебіг вагітності, розвиток плода, пологовий і післяпологовий періоди. Стало питання у виборі активних безмедикаментозних безпечних методів лікування, яким, на нашу думку, є хірургічне втручання у II або III триместрах вагітності.

Проведено аналіз даних, отриманих при дуплексному скануванні 768 вагітних пацієнток із варикозним розширенням підшкірних вен промежини, зовнішніх статевих органів, нижніх кінцівок, відповідно до яких ми розробили протокол дуплексного сканування, де виділили “вузлові ділянки” венозної системи, які в більшості випадків, на нашу думку, є пусковим механізмом розвитку варикозного розширення підшкірних вен: 1 - ділянка пахового каналу; 2 - ділянка зовнішніх статевих органів і промежини; 3 - підшкірно-стегнова ділянка; 4 - підшкірно-підколінна ділянка; 5 - ділянки перфорантних вен на стегні i/або гомілці; 6 - стан прохідності глибоких вен нижніх кінцівок і таза.

Ускладнення під час обстеження мали місце у 12 (1,6 \%) вагітних у вигляді легкого затьмарення свідомості при проведенні проби Вальсальви. У 23 (2,99 \%) вагітних виникли легкі прояви ортостатичного колапсу при їх перебуванні в нерухомому стані - “стоячі” через перерозподіл об’ємів крові. Для запобігання цьому вагітні періодично виконували ходьбу на місці.

Основною причиною прогресуючого варикозного розширення підшкірних вен нижніх кінцівок, зовнішніх статевих органів і промежини серед 390 обстежених були ПВР у гілки проксимального відділу системи великої підшкірної вени у 328 (84,1 \%) випадках, із системи внутрішньої клубо- 
вої вени через систему яєчникових i/або маткових вен по паховому каналу у 38 (9,74 \%) пацієнток, через систему v. pudenda int. - v. obturatorica y 24 $(6,15 \%)$ вагітних.

Найчастіше - у 288 (73,85 \%) обстежених формування прогресуючого варикозного розширення підшкірних вен зовнішніх статевих органів і промежини зустрілось в поєднанні із варикозним розширенням підшкірних вен нижніх кінцівок, а як ізольований варіант у 102 (26,15 \%) вагітних. Однобічний характер ураження виявили у 73 (71,6 \%) вагітних, а у 29 (28,4 \%) пацієнток ураження мали двобічний характер. Ці форми варикозного розширення зустрілись у 81 \% вагітних, які мали двоє пологів і більше. За даними дуплексного сканування, ПВР виникає через некомпетентність (неспроможність) остіального клапана в підшкірно-стегновому з'єднанні, через який він із загальної стегнової вени поширюється у проксимальний відділ ВПВ та в її гілки, що впадають у цей відрізок, у такому поєднанні: у 115 (40 \%) вагітних ПВР поширювався у зовнішню соромітну вену, додаткову бічну вену і проксимальний відділ ВПВ, у 86 (30 \%) обстежених ПВР поширювався в зовнішню соромітну вену, латеральну й медіальну додаткові вени та в початковий відділ ВПВ, у 44 (15 \%) вагітних виявлено ПВР у зовнішню соромітну вену, латеральну й медіальну додаткові вени, зовнішню епігастральну вену та в початковий відділ ВПВ (рис. 1). Серед 61 (8 \%) пацієнтки виявлено подвоєння стовбура великої підшкірної вени. У більшості випадків він (82 \%) не зазнавав варикозної трансформації, тоді як гілки, які відходили від нього на стегно у верхній третині і/ або нижній третині, зазнали варикозної трансформації у вигляді варикозних конгломератів і розташовувались у підшкірній жировій клітковині між поверхневою фасцією і шкірними покривами. У 68 пацієнток діагностовано значну флебектазію v. pudenda ext, яка у 8 випадках досягала до 20 мм у діаметрі і проявляла себе клінічно у вигляді пахової грижі, у 6 пацієнток флебектазія діаметром до 10 мм; клінічно скарги на виражену локальну болючістю, що обмежувало фізичні навантаження у вагітної (рис. 1, А). Серед 120 обстежених вона найчастіше досягала 4-6 мм у діаметрі і формувала варикоз зовнішніх статевих органів. V. saphena accesoria medialis у 123 обстежених вагітних брала участь у формуванні варикозного розширення зовнішніх статевих органів і підшкірних вен по медіальній поверхні стегна у верхній третині з переходом на промежину, а в 23 випадках анастомозувала з вітками малої підшкірної вени. Крім того, у 86 (11,2 \%) обстежених ПВР також поши-
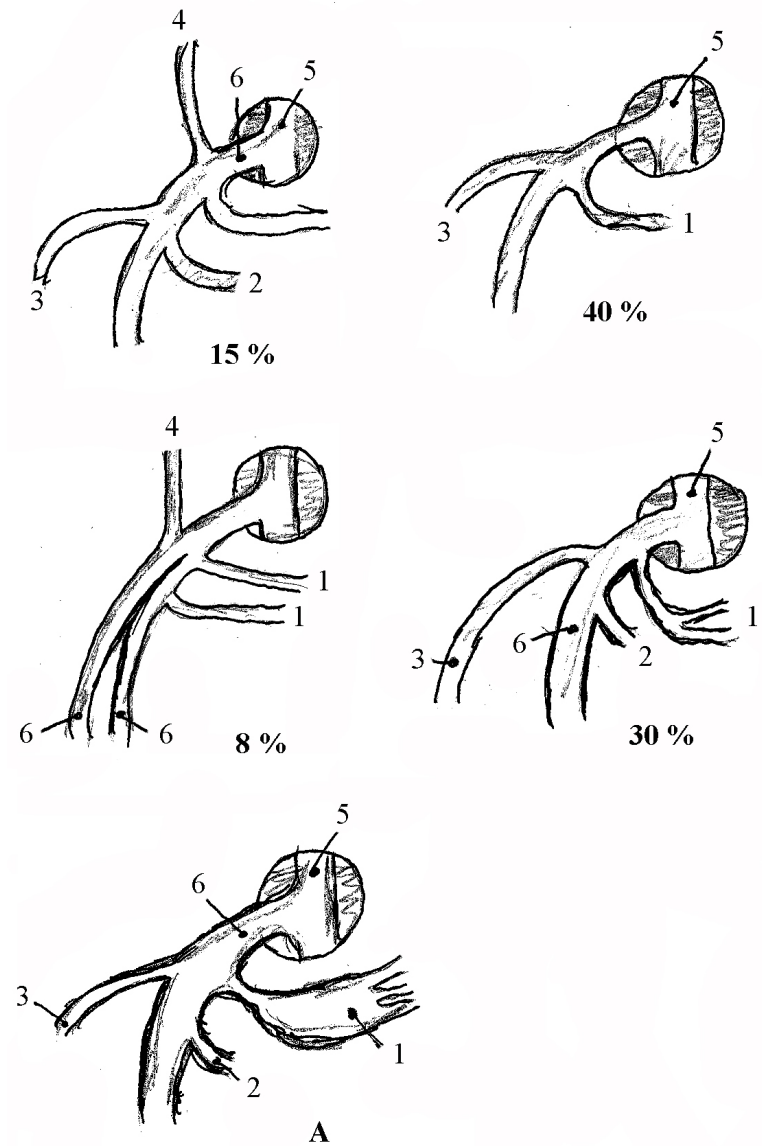

Рис. 1. Схема підшкірно-стегнового співустя: 1 v. pudenda externa; 2 - v. saphena accesoria medialis; 3 v. saphena accesoria lateralis; 4 - v. epigastrica superficialis; 5 - v. femoralis com; 6 - v. saphena mag.

рювався по стовбуру ВПВ по всій довжині стегна, у 12 (1,56 \%) обстежених по довжині стегна та гомілки, що клінічно проявлялось поєднанням варикозного розширення вен зовнішніх статевих органів, промежини і нижніх кінцівок. Серед 38 $(9,74$ \%) вагітних ПВР поширювався через вісцеральні гілки внутрішньої клубової вени (маткові 16 (42,1 \%), яєчникові 11 (28,94 \%), внутрішню соромітну 7 (18,42 \%) вени і ще рідше через гілки зовнішньої клубової вени (нижня клубова вена та її вітка v. cremaster) у 4 (10,52 \%) вагітних. У 18 (47,36 \%) обстежених виявили поєднання рефлюксів у ці гілки. Вищеперераховані гілки проходять через паховий канал, поширюючись на статеві губи та промежину, і формують їх варикозне розширення (рис. 2).

Крім того, слід відмітити, що варикозні вени різних венозних басейнів (великої підшкірної вени, системи парієтальних і вісцеральних гілок внутрішньої клубової вени), які містяться в тілі статевих губ, не анастомозуються між собою, а анастомозуються між собою гілки однойменних басейнів $з$ протилежних сторін. 


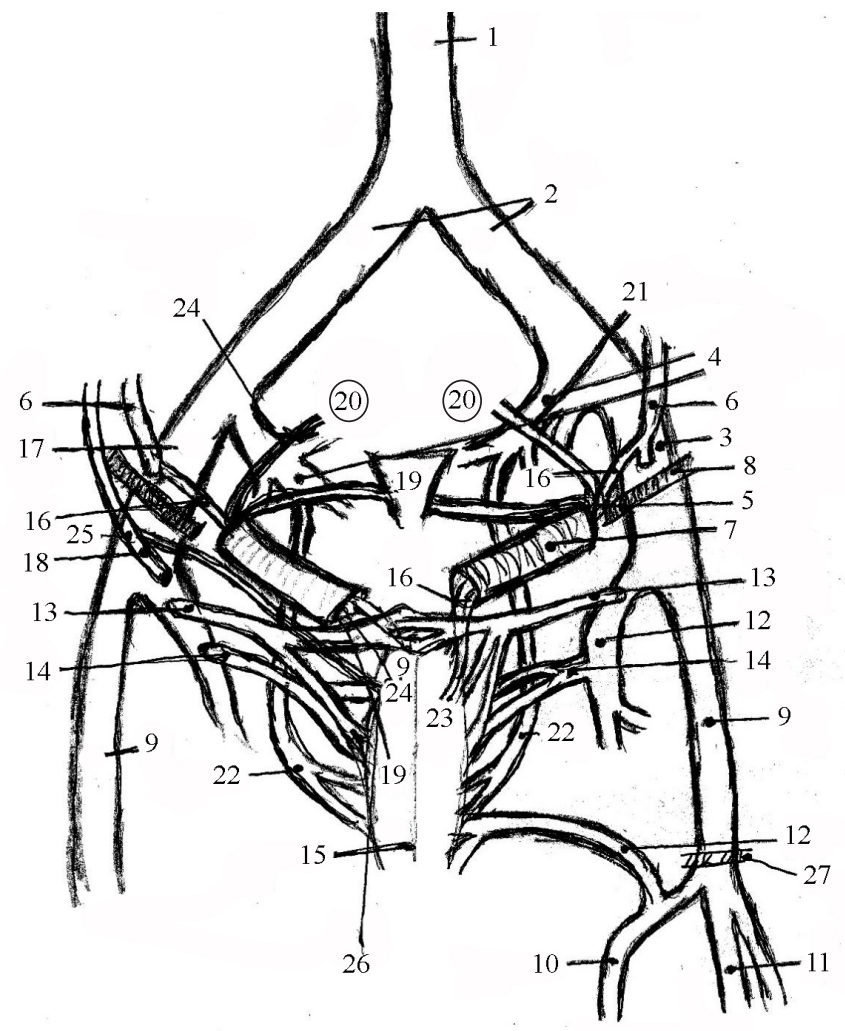

Рис. 2. Схема кровотоку при формуванні варикозного розширення підшкірних вен зовнішніх статевих органів: 1 - нижня порожниста вена; 2 - загальна клубова вена; 3 -зовнішня клубова вена; 4 - внутрішня клубова вена; 5 - яєчникова вена; 6 - нижня надчеревна вена; 7 - паховий канал; 8 - пахова зв'язка; 9 стегнова вена; 10 - мала підшкірна вена; 11 - глибокі вени гомілки; 12 - велика підшкірна вена; 12.1 - вітки малої підшкірної вени; 13 - зовнішня соромітна вена; 14 - додаткова медіальна вітка; 15 - зовнішні статеві органи; 16 - v. cremaster ext.; 17 - зовнішня клубова вена; 18 - вени зовнішньої надчеревної вени; 19 - матка; 20 - яєчники; 22 - внутрішня соромітна вена; 24 вени матки; 25 - зовнішня надчеревна вена; 27 - колінна суглобова щілина.

У 2 (\%) пацієнток через гілки басейну малої підшкірної вени дренувалась венозна кров у систему вен зовнішніх статевих органів з причини уродженої артеріовенозної мальформації з гіпоактивними артеріовенозними норицями в дистальній частині гомілки.

Дані УЗД дослідження свідчать, що особливістю в розвитку варикозного розширення підшкірних вен у вагітних із підозрою на недиференційовану дисплазію сполучної тканини (7,9%) є поширеність розширення підшкірних вен одночасно в басейнах як малої і великої підшкірних вен, так і перфорантних вен на стегні і/ або гомілці, із змінами гемодинаміки по них. Відмічено одночасне існування як горизонтальних, так і вертикальних ПВР.
У 1,5 \% пацієнток виявлено формування вторинного варикозного розширення підшкірних вен стегна, промежини, зовнішніх статевих органів. Це сформована венозна колатеральна сітка, що стало проявом порушення венозного крововідтоку по глибоких венах нижніх кінцівок та клубових венах як результат перенесеного флеботромбозу глибоких вен нижніх кінцівок і таза.

Висновки. 1. Розроблено протокол дуплексного сканування, в якому виділені вузлові ділянки венозної системи, які в більшості випадків $\epsilon$ пусковим механізмом розвитку варикозного розширення підшкірних вен: 1 - ділянка пахового каналу; 2 - ділянка зовнішніх статевих органів і промежини; 3 - підшкірно-стегнова ділянка; 4 підшкірно-підколінна ділянка; 5 - ділянка перфорантних вен на стегні і/або гомілці; 6 - прохідність глибоких вен нижніх кінцівок і таза.

2. Для отримання достовірних даних дослідження вен у вагітних у 100 \% виконували в поєднанні положення лежачи на лівому боці під кутом 30 градусів і стоячого положення (ортостазі), коли напружені м'язи нижніх кінцівок, особливо м'язи гомілок (включена м'язова помпа гомілки). Ортостаз (ортодинаміка) ближче всього до фізіологічного стану. І окрім того, таке положення вагітної на лівому боці запобігає розвитку в цієї категорії пацієнток (коли дослідження проводяться в горизонтальному положенні обстеженої), особливо при кінці II і впродовж III триместрів вагітності, розвитку синдрому нижньої порожнистої вени або аортокавального синдрому. Крім того, використовували пробу Вальсальви, яка особливо важлива для виявлення та вивчення наявності патологічного рефлюксу шляхом збільшення венозного потоку в стані спокою.

3. Дуплексне сканування не $є$ інвазійним методом, не викликало ятрогенних ускладнень як 3 боку вагітної, так і плода. Це дослідження надало майже всі дані, які необхідні для встановлення діагнозу варикозу, сприяло можливості оцінити динаміку процесу і вибрати стратегію подальшого лікування.

4. У вагітних має місце обмеження дуплексного сканування, особливо ділянок клубових вен (загальних клубових вен, внутрішніх клубових та початкового відділу порожнистої вени) за рахунок вагітної матки, яка перекриває доступ до огляду вищеперерахованих відрізків вен.

Перспективи подальших досліджень. Перспективним $є$ дуплексне сканування не тільки для з'ясування причин розвитку даної патології, але й 
для вивчення анатомії венозної системи прогресуючої варикозної хвороби вищеперерахованих ділянок із плануванням доцільності та по можливості безпечної хірургічної корекції даної патології 3 визначенням об’єму операційного втручання під час вагітності з метою активної безмедикаментоз- ної профілактики прогресування варикозного розширення підшкірних вен та запобігання ускладненням варикозного розширення підшкірних вен під час вагітності, пологів і в післяпологовому періоді у вигляді акушерських кровотеч, тромботичним і/або тромбемболічним ускладненням.

\section{СПИСОК ЛІТЕРАТУРИ}

1. Бурлева Е. П. Связь промежностного венозного рефлюкса со стволом большой подкожной вены при варикозной болезни / Е. П. Бурлева, В. С. Бочегов, Р. Р. Фасхиев // XI научно-практическая конференция Ассоциации флебологов России. Новосибирск, 24 июня 2016 г. : материалы конференции. - 2016. - Т. 10, вып. 2. - № 2. - С. 86.

2. Вульварный варикоз: диагностика, лечение, профилактика / С. Г. Гаврилов, Е. П. Москаленко, А. В. Каралкин [и др.] // Анн. хирургии. - 2014. - № 4. - С. 14-16.

3. Долго-Сабуров Б. А. Анастомозы и пути окольного кровообращения у человека / Б. А. Долго-Сабуров. - Л. : Медгиз, 1956. 4. Иванов Г. В. Основы нормальной анатомии человека в 2 томах / Г. В. Иванов. - М. : Медгиз, 1949.

5. Крылова Н. В. Анатомия венозной системы (в схемах и рисунках) / Н. В. Крылова, Н. И. Волосок. - М. : ООО “Медицинское информационное агентство”. - 2006. - 112 с.

6. Кирпатовский И. Д. Очерки по хирургической андрологии / И. Д. Кирпатовский. - М. : Изд-во УДН, 1989. - 125 с.

7. Український Консенсус з лікування пацієнтів з варикозною хворобою нижних кінцівок. - К., 2005.

8. Петров В. В. Сегментарная флебектомия у беременных с прогрессирующей варикозной болезнью вен нижних конечностей : автореф. дисс. на соискание учёной степени канд. мед. наук / В. В. Петров. - СПб., 2011.

9. Хирургическое лечение варикозной болезни у беременных / К. В. Новиков, В. В. Воробьев, В. Г. Абашин [и др.] // Амбулаторная хирургия. - 2009. - № 3-4 (35-36). - С. 40-41.

10. Шевченко Ю. Л. Основы клинической флебологии / Ю. Л. Шевченко, Ю. М. Стойко, М. И. Лыткина. - М. : ОАО:

\section{REFERENCES}

1. Burleva, E.P., Bochegov, V.S., \& Faskhiev, R.R. (2016). Sviaz promezhnostnogo venoznogo refliuksa so stvolom bolshoi podkozhnoi veny pri varikoznoi bolezni [Relation of perineal venous reflux to the trunk of the large saphenous vein in varicose veins]. XI nauchno-prakticheskaia konferentsyia assotsiatsii flebologov Rossii - XI Scientific and Practical Conference of the Russian Phlebology Association. (p. 86). Novosibirsk: Flebologiia.

2. Gavrilov, S.G., Moskalenko, E.P., \& Karalkin, A.V. (2014). Vulvarnyi varikoz: Diagnostika, lechenie, profilaktika [Vulvar varicose veins: Diagnosis, treatment, prevention]. Ann. Khirurgii - Annals of Surgery, 4, 14-16 [in Russian].

3. Dolgo-Saburov, B.A. (1956). Anastomozy i puti okolnogo krovoobrashcheniia u cheloveka [Anastomoses and circulatory pathways in humans]. Lvov: Medgiz [in Russian].

4. Ivanov, G.V. (1949). Osnovy normalnoi anatomii cheloveka $v 2$ tomakh [Fundamentals of normal human anatomy in 2 volumes]. Moscow: Medgiz [in Russian].

5. Krylova, N.V., \& Volosok, N.I. (2006). Anatomiia venoznoi sistemy ( $v$ skhemakh i risunkakh) [Anatomy of the venous system (in schemes and illustrations)]. Moscow: "OOO” Meditsinskoe informatsionnoe agenstvo [in Russian].

“Издательство “Медицина”, 2005. - 312 с.

11. Краткий курс оперативной хирургии с топографической анатомией / под ред. В. Н. Шевкуненко, А. Н. Максименкова. - Л. : Медгиз,1951. - 796 с.

12. Pelviperineal venous insufficiency and varicose veins of the lower limbs / E. Balian, J.-L. Lasry, G. Coppe [et al.] // Phlebolymphlogy. - 2008. - Vol. 15, №1. - P. 17-26

13. Vulvar varices an uncommon entity in surgical pathology / D. Bell, P. B. Kane, S. Liang [et al.] // Int. J. Gynecol. Pathol. 2007. - Vol. 26 (1). - P. 99-101

14. Dodd $H$. The pathology and surgery of the veins of the lower limb/-2 ${ }^{\text {nd }}$ ed / H. Dodd, F. B. Cockett. - Edinburg: Churchill Livingstone, 1976. - 323 p.

15. Fassiadis N. Treatment for pelvic congestion syndrome causing pelvic and vulvar varices / N. Fassiadis // Int. Angiol. 2006. - Vol. 25(1). - P.1-3.

16. Frede T. E. Ultrasonic visualization of varicosities in the female genital tract / T. E. Frede // J. Ultrasound Med. - 1984. Vol. 3. - P. 365-369.

17. Fronek H. S. The fundamentals of phlebology:venous disease for clinicians / H. S. Fronek // American College of Phlebology. $-2008$.

18. Ramelet A. A. Les varices et telangiectasies / A. A. Ramelet, P. Kern, M. Perrin // Masson. - Paris, 2008.

19. Nguyen Q.H.Dopplersonography in the diagnosis of round ligament varicosities during pregnancy / Q. H. Nguyen, S. M. Grunewald // J. Clin. Ultrasound. - 2008. - Vol. 36. - P. 177-179.

20. Sodhi M. S. Venous anatomy of the sapheno-femoral area / M. S. Sodhi, H. Dodd // Brit. J. Surge. - 1967. - Vol. 54. - P. 15.

6. Kirpatovskii, I.D. (1989). Ocherki po khirurgicheskoi andrologii [Essays on surgical andrology]. Moscow: Izd-vo UDN [in Russian]. 7. (2005). Ukrainskyi Konsensus z likuvannia patsiientiv z varykoznoiu khvoroboiu nyzhnykh kintsivok - Ukrainian consensus on patients with varicose veins of the lower extremities. Kyiv [in Ukrainian].

8. Petrov, V.V. (2011). Segmentarnaia flebektomiia u beremennykh s progressiruiushchei varikoznoi bolezniu ven nizhnikh konechnostei [Segmental flebectomy in pregnant women with progressive varicose veins of the lower extremities]. Extended abstract of candidate's thesis. Saint-Petersburg [in Russian]

9 Novikov, K.V., Vorobev, V.V., \& Abashin, V.G. (2009). Khirurgicheskoe lechenie varikoznoi bolezni ven nizhnikh konechnostei u beremennykh [Surgical treatment of varicose veins of the lower extremities in pregnant women]. Ambulatornaia khirurgiia - Ambulatory Surgery, 3-4, 40-41 [in Russian].

10. Shevchenko, Yu.L., Stoiko, Yu.M., Lytkina, M.I. (2005). Osnovy klinicheskoi flebologii [Fundamentals of clinical phlebology]. Moscow: OAO. Izdatelstvo. Meditsina [in Russian].

11. Shevkunenko, V.N. (1951). Kratkii kurs operativnoi khirurgii $s$ topograficheskoi anatomiei [Short course of operative surgery with topographic anatomy]. Lvov: Medgiz [in Russian]. 
12. Balian, E., Lasry, J.-L., Coppe, G., \& Borie, H. (2008). Pelviperineal venous insufficiency and varicose veins of the lower limbs. Phlebolymphlogy, 15 (1), 17-26.

13. Bell, D., Kane, P.B., Liang, S., Conway, C., \& Tornos, C. (2007). Vulvar varices an uncommon entity in surgical pathology. Int. J. Gynecol. Pathol., 26 (1), 99-101.

14. Dodd, H., \& Cockett, F.B. (1976). The pathology and surgery of the veins of the lower limb/-2nd ed. Edinburg: Churchill Livingstone.

15. Fassiadis, N. (2006). Treatment for pelvic congestion syndrome causing pelvic and vulvar varices. Int. Angiol. 25 (1), 1-3.
16. Frede, T.E. (1984). Ultrasonic visualization of varicosities in the female genital tract. J. Ultrasound Med. 3, 365-369.

17. Fronek, H.S. (2008). The fundamentals of phlebology: venous disease for clinicians. American College of Phlebology.

18. Ramelet, A.A., Kern, P., \& Perrin, M. (2008). Les varices et telangiectasies. Masson: Paris.

19. Nguyen, Q.H., \& Grunewald, S.M. (2008). Doppler sonography in the diagnosis of round ligament varicosities during pregnancy. J. Clin. Ultrasound, 36, 177-179.

20. Sodhi, M.S., \& Dodd, H. (1967). Venous anatomy of the sapheno-femoral area. Brit. J. Surg., 54, 15.

\title{
V. M. ANTONYUK-KYSIL ${ }^{1}$, V. M. YENIKEEVA ${ }^{1}$, S. I. LICHNER ${ }^{1}$, V. M. LYPNYY ${ }^{1}$, M. V. SEMENYUK ${ }^{2}$
}

Public Facility «Rivne Regional Perinatal Center» of Rivne Regional Council ${ }^{1}$

«LOKO» Ltd., Rivne ${ }^{2}$

\section{DUPLEX SCANNING OF ATYPICAL FORMS OF PROGRESSIVE VARICOSE SAPHENOUS VEINS DISEASE IN PREGNANT WOMEN (EXTERNAL GENITALIA, PERINEUM)}

\begin{abstract}
The aim of the work: to examine sources and options of progressive varicose saphenous veins disease of the perineum, external genitalia during pregnancy using the data of duplex scanning.

Materials and Methods. 768 (93.03 \%) patients were examined according to the protocol developed by us among 825 pregnant women with varicose veins of the lower extremities, perineum, external genitalia, inguinal canal who gave birth in the Regional Perinatal Center from the beginning of 2013 till 2016 inclusive.

Results and Discussion. The main available currently, dynamic, informative, less traumatic for pregnant women and fetus method of examination of the venous system of the pelvis, perineum and lower extremities, groin in progressive varicose veins in these areas is duplex scanning. Duplex scanning was carried out to study the anatomy of the venous system of progressive varicose veins disease of above mentioned areas with planning feasibility and possibility of safe surgical correction of this pathology with the definition of the volume of surgical intervention during pregnancy. One of the stages of duplex scanning is to identify areas with pathologic reflux, defined by us as "nodal areas" of the venous system, which according to our data are in most cases a trigger mechanism of development and cause of progression of varicose saphenous veins of above mentioned areas.
\end{abstract}

Key words: causes of progressive varicose veins disease in pregnant women; varicose veins of vulva and perineum; duplex scanning of veins.

\author{
В. М. АНТОНЮК-КИСЕЛЬ ${ }^{1}$, В. М. ЕНИКЕЕВА ${ }^{1}$, С. И. ЛИЧНЕР ${ }^{1}$, В. М. ЛИПНЫЙ ${ }^{1}$, М. В. СЕМЕНЮК
}

КУ “Ровенский областной перинатальный центр” Ровенского областного совета ${ }^{1}$

ООО “ЛОКО", г. Ровно ${ }^{2}$

\section{ДУПЛЕКСНОЕ СКАНИРОВАНИЕ НЕТИПИЧНЫХ ФОРМ ПРОГРЕССИРУЮЩЕЙ ВАРИКОЗНОЙ БОЛЕЗНИ ПОДКОЖНЫХ ВЕН У БЕРЕМЕННЫХ (НАРУЖНЫХ ПОЛОВЫХ ОРГАНОВ, ПРРОМЕЖНОСТИ)}

\begin{abstract}
Цель работы: изучить, используя данные дуплексного сканирования, источники и варианты прогрессирующей варикозной болезни подкожных вен промежности, наружных половых органов во время беременности.

Материалы и методы. Обследовано согласно разработанному нами протоколу 768 (93,03 \%) пациенток с 825 беременных с варикозной болезнью нижних конечностей, промежности, наружных половых органов, пахового канала, родивших в областном перинатальном центре с начала 2013 по 2016 г. включительно.

Результаты исследований и их обсуждение. Основным доступным в настоящее время, динамичным, информативным, малотравматичным для беременных и плода методом обследования венозной системы таза, промежности и нижних конечностей, паха при прогрессирующем варикозном расширении вен в этих участках является дуплексное сканирование. Дуплексное сканирование проводили для изучения анатомии венозной системы прогрессирующей варикозной болезни вышеперечисленных участков с планированием целесообразности и по возможности безопасной хирургической коррекции данной патологии с определением объёма оперативного вмешательства во время беременности. Одним из этапов дуплексного сканирования является выявление зон с патологическим рефлюксом, определенных нами как “узловые участки” венозной системы, которые, по нашим данным, в большинстве случаев являются пусковым механизмом развития и причиной прогрессирования варикозного расширения подкожных вен вышеперечисленных участков.
\end{abstract}

Ключевые слова: причины прогрессирующей варикозной болезни у беременных; варикозное расширение вен вульвы и промежности; дуплексное сканирование вен. 